Vol. 4, No. 1, 2018

УДК: 327.8

СТРАТЕГІЯ НЕПРИСДНАННЯ: ПОЛІТИКА І ТЕОРІЯ

\author{
Олег Цебенко \\ Національний університет “Львівська політехніка" \\ ol.tsebenko@gmail.com \\ ORCID: 0000-0002-0024-0405
}

Олександр Шимчук

Вільнюський університет

ol.shymchuk@ukr.net

ORCID: 0000-0001-6123-3228

(стаття надійшла до редколегї-05.01.2018 р., прийнята до друку - 16.04.2018 р.)

() Цебенко О., Шимчук О., 2018

Досліджено політику неприсднання як одину з ключових стратегій діяльності держави у міжнародних відносинах. Проаналізовано основні теоретичні та методологічні підходи дослідження політики неприсднання, виокремлено дефініції цього поняття та виявлено ключові ознаки стратегії неприсднання держав. Простежено історичний аспект виникнення ідеї руху неприсднання. Досліджено вплив глобалізації на зміну політики неприсднання та нейтралітету держав.

Члени Руху неприсднання зобов'язані, як зазначено в Гаванській декларації 1979 року, забезпечити національну незалежність, суверенітет, територіальну цілісність та безпеку країн, що неприсдналися “у їх” боротьбі проти імперіалізму, колоніалізму, неоколоніалізму, расизму та всіх форм зовнішньої агресії, окупації, панування, втручання або гегемонії, а також проти політики великої держави та блоку.

Політика неприєднання вимагає від держави, яка слідує за її принципами реалізації зовнішньополітичних намірів, спрямованих на поділ світу на два ворожі блоки.

Декларуючи статус неприсднання статусу, держава передусім стежить за внутрішніми чинниками, економічними або політичними, та зовнішніми чинниками, тобто сильною економічною незалежністю, можливістю зовнішньополітичного або військового тиску. Крім того, курс на неприсднання є можливим лише за відсутності будь-яких очевидних або прихованих територіальних претензій до держави, яка прагне проводити політику неприсднання.

Беручи до уваги реалізації статусу неприсднання, держава краще базується на досвіді свропейських вже неприсднаних держав, а також сьогодні міжнародній ситуації. Однак сучасні умови дещо змінюють концепцію неприсднання.

Ключові слова: неприєднання, нейтралітет, стратегія, безпека, глобалзація.

\title{
NON-ALIGNMENT STRATEGY: POLITICS AND THEORY
}

\author{
Oleh Tsebenko \\ Lviv Polytechnic National University \\ ol.tsebenko@gmail.com \\ ORCID: 0000-0002-0024-0405 \\ Oleksandr Shymchuk \\ University of Vilnius \\ ol.shymchuk@ukr.net \\ ORCID: 0000-0001-6123-3228
}

The complex study of the state non-alignment strategy is done. The theoretical and methodological basis of nonalignment strategy is analyzed, the problem of definition this phenomenon is investigated, the main aspects of neutrality strategy tendencies are clarified. The historical aspects of non-alignment policies are developed.

The Non-alignment Movement members were obliged as stated in the Havana Declaration of 1979 to ensure the national independence, sovereignty, territorial integrity and security of non-aligned countries "in their" struggle 
against imperialism, colonialism, neo-colonialism, racism, and all forms of foreign aggression, occupation, domination, interference or hegemony as well as against great power and bloc politics.

A policy of non-alignment required from a state that follows its principles implementation of foreign policy intentions aiming to overcome the world's partition into two hostile blocs.

Declaring a non-aligned status a state first of all followed internal causes, that are economical or political calamities, and external motives, that is strong economic dependence, possibility for foreign policy or military pressure. Furthermore, a course for non-alignment is only possible for lack of any evident or implemented territorial claims to a state that aims to pursue a politics of non-alignment.

Taking into account a process of the implementation of a non-aligned status, a state had better rely on the experience of the European already non-aligned states as well as today's international situation. Yet, modern conditions somewhat modify the concept of non-alignment. One can argue, but nowadays, for instance an expression "abstention form permanent alignment with blocs" might sound somewhat weird and with some ideological hue. A word "bloc" is considered anachronism in the modern dictionary of international relations, it rather an echo of the Cold War times; therefore, nonalignment as the concept has to be tied down to modern time and be able to deal with modern definitions.

Key words: non-alignment, neutrality, strategy, security, globalization.

After World War II, a wave of nationalism swept across Asia and Africa, and in its wake a host of new nations proclaimed independence from their European colonial masters. Within two decades about one-third of the world's population was freed from colonial rule [Williams 2005:109].

Indeed, different kinds of political transformations in Asian and to certain degree in African nations had been developing since about the beginning of the twentieth century, and by the end of World War II they had led to the emergence of the new forms of already independent states' policies. If World War I marked the beginning of the formation of a new system of international relations that was mainly based on the confrontation of two superpowers and blocs with their own ideological perception of the world, then, in time, a bipolar system provided for the existence of the appropriate form of neutrality, which was a peculiar combination of the negative reaction of post-colonial states with their modern intentions.

The Non-Aligned Movement that was founded in Belgrade in 1961 offered the Third World countries a new neutral alternative of their participation in a global race of superpowers and blocs. Like Leo Mates put in his fundamental work Nonalignment-theory and current policy: "What mattered was not the number of the nonaligned, but the fact that these countries were only gradually able to abandon their own internal of immediate preoccupation and form their own policies and modes of international activity. The new countries became non-aligned first in the consciousness of their political leaders and statesmen and only afterward in the practice of their international behaviour. They were, in fact, non-aligned from the very first day of their real independence, but became known as such only later on.[Mates 1972: 74-75]".

Although the concept of non-alignment is often confused with "neutrality", "passivity" or "noninvolvement" by now it has been quite clearly stated by the "non-aligned" themselves what the concept means. It does not mean adherence to the rule of non-involvement, refusing to take sides in any inter-state dispute to which the country is not a direct party. It would go to the extent of taking sides in the dispute but, as a matter of principle, they (non-aligned) declared themselves against any permanent or long-term involvement on the side of one or the other of the parties to the Cold War. This would constitute alignment.

Under the impact of the Cold War, the most important basis of non-alignment was this "negative" abstention from permanent alignment with either bloc[Hveem, Willets 1975: 1]. John Burton somewhat clarified the criteria of non-aligned state. So, that a state: "[...] belonged to neither the Communist nor the Western military bloc; that it had no bilateral military arrangement with a bloc country; that it either had no foreign military base on its soil or was' opposed to those which were there; that it supported liberation and independence movements; and that it pursued an independence policy based on peaceful co-existence [Burton 1975: 2]".

In general, a policy of non-alignment required from a state that follows its principles implementation of foreign policy intentions aiming to overcome the world's partition into two hostile blocs.

The Non-alignment Movement members were obliged as stated in the Havana Declaration of 1979 to ensure "[...]the national independence, sovereignty, territorial integrity and security of non-aligned countries" in their "struggle against imperialism, colonialism, neocolonialism, racism, and all forms of foreign aggression, occupation, domination, interference or hegemony as well as against great power and bloc politics [Castro 1979]".

Denial of block confrontation and defence of the principles of peace co-existence was nothing, but modification of neutrality under new conditions of antiwar sentiments. The Non-alignment Movement members' foreign policy intentions to abstain from participation in different military-political unions and blocs, which were established by direct involvement or under the protectorate of one of the great powers 
involved in bipolar confrontation, was a strong argument for the aforementioned statement. Non-aligned states spoke in the transformation of the whole world community. First of all, it concerned the world's division into antagonistic military-political blocs and eventually caused debates between theorists, concerning nonalignment and states' participation in military-political blocs and/or unions.

Realists considered power, and not in the last place, its military implication the paramount tool to ensure both the internal and external security of the state. In this context, alliances, blocs and unions are seen as the peculiar instruments to strengthen security that, in turn, helps to more efficiently resist certain threats and, respectively, facilitate the balance of power support in the anarchic international environment.

Of course, allies' clear commitments in the systems of collective defence significantly decrease the level of expenditures on the support of the necessary state of national security for all the allies. Besides, a participation in political and/or military-political alliances and blocs together with great powers is considered the effective tool to strengthen international image of a state and the efficiency of the implementation of its foreign policy strategy.

However, in spite of the set of advantageous, a participation in alliances and blocs has serious shortcomings, which might lead to the direct danger. Therefore, according to certain researchers "[...]states should avoid them except when absolutely necessary" [Kegley, Wittkopf 1997: 444].

Moreover, rapid changes in the international relations often cause default on allied obligations that might in turn cause threat to a national security of a state. Under these circumstance, the balance of power, maintenance of good-neighbourly relations among all sides of conflict, multi-vector policy are no longer considered means to efficiently pursue state politics.

Another shortcoming of a state's participation in alliances and/or blocs is an increase of the risk to be involved in war or conflicts that were started by other allies. What is potentially dangerous is that a state might face a threat of division in society due to the people's unwillingness to fight a strange war, to use soldiers as cannon fodder.

Besides, there are some solely psychological consequences of the participation in blocs. Strengthening of any state, including the establishment of alliances and blocs, might be considered by a potential adversary as a direct threat to its national security. This leads to socalled security dilemma that refers to a situation in which actions by a state intended to heighten its security, such as increasing its military strength or making alliances, can lead other states to respond with similar measures, producing increased tensions that create conflict, even when no side really desires it.
Hence, shortcoming and potential dangers related to state's participation in military and/or political alliances and blocs led many scholars draw a conclusion in Machiavelli's' fashion, that: '[...] the only good alliance is one that can be dissolved easily when the threat to one's own security declines. As Britain's Lord Palmerston admonished in 1848, states "should have no eternal allies and no perpetual enemies". Their only duty, then, is to follow their interests, which may require abandoning an ally when it ceases to be useful [Kegley,Wittkopf 1997: 445]".

Declaring a non-aligned status a state first of all followed internal causes, that are economical or political calamities, and external motives, that is strong economic dependence, possibility for foreign policy or military pressure. Furthermore, a course for non-alignment is only possible for lack of any evident or implemented territorial claims to a state that aims to pursue a politics of non-alignment.

Compared to the traditional concept of neutrality, non-alignment offers a somewhat broader political springboard for further actions Noteworthy, a nonaligned status might be unilaterally reconsidered at any moment, herewith a state does not necessarily default its obligations. This may happen when a state is no longer capable under the specific international situation to independently ensure its national security and consequently cannot, but accede to a certain alliance. One may argue that non-alignment politics has been considered efficient, but not always good-chosen state's foreign policy strategy. Nonetheless, certain states, for instance Finland, started to implement non-alignment politics that was mainly imposed by the imminent rivalry of the two blocs, and they began to diverge from such politics only then, when geopolitical priorities and the level of war menace had slightly changed.

One can argue with Hveem and Willets that "[...] the concept of non-alignment excludes permanent political, military, diplomatic or economic alignments with any big powers as incompatible with it. [Hveem, Willets 1975: 35]" And if one takes it that the success of non-alignment depends on a wish of specific country, he has to be aware of positive perception of such a status by all competing sides, blocs or alliances. Herewith, there should not be neither evident nor clandestine efforts to win non-aligned states over or oppose recognition and affirmation of its non-aligned status worldwide.

However, taking into account a process of the implementation of a non-aligned status, a state had better rely on the experience of the European already nonaligned states as well as today's international situation. Yet, modern conditions somewhat modify the concept of non-alignment. One can argue, but nowadays, for instance an expression "abstention form permanent alignment with blocs" might sound somewhat weird and with some ideological hue. A word "bloc" is considered 
anachronism in the modern dictionary of international relations, it rather an echo of the Cold War times; therefore, non-alignment as the concept has to be tied down to modern time and be able to deal with modern definitions.

The end of bipolar confrontation, appalling realties of the $\mathrm{XX}$ centuries, and the consequent development of advanced technologies changed the concept and system of the international relations.

This period as Stephanie Lawson noted: "[...] has been characterized temporarily as post-Cold War and materially or technically as one of advanced globalization. And there is an assumption-or at least perception- of a strong correlation between the collapse of the bipolar world order in 1989, symbolized most dramatically and televisually by the fall of the Berlin Wall, and the gathering of an irresistible momentum in globalization from around that time which is destined radically to transform the face of world order. [Lawson 2002: 205]"

A definition "globalization" in its modern understanding emerged in the mid-1980s and resulted in the strong influence over the whole intellectual elite. The emergence of the definition is linked up with a name of Theodore Levitt. The researcher in his article in "Harvard business review" in 1983 used this notion to define an amalgamation of markets of certain goods, manufacturing by large multinational corporations [Удовик 2002:1].

Already in the mid-1990s, the term "globalization" became a buzzword to describe the growing integration of the international economy. Globalization was the new reality, it was argued; one had better got on board or be left behind. "A rising tide", the promoters of globalization argued, "lifts all boats. [Williams, Piotrkowski 2006: 444].

However, despite wide-ranging changes, it is argued by many scholars that the process of globalization is fluid and unfinished: in effect, that global politics represents a transnational world, containing elements of many cultures, political practices and power structures. Under these conditions, the concept of the nation-state and its role in a global politics, beyond dispute, significantly changes. Thus, all up to date neutral states, like it has been argued before, came across the expediency of the preservation of a neutral status and likewise implementation of either limitation to neutrality. And while international perceptions are clearly prerequisites to credibility, one may argue that neutrality is not anymore in the eye of the beholder, but in the selfimposed limits of declared neutrals.

With neutral countries joining international institutions and participating in sanctions, permanent neutrality appears to be on a slippery slope to oblivion. The emerging norm for the 21 st century a neutral seems to be one which renounces war fighting and collective hard security commitments, but seeks active political engagement and full economic integration in world markets.

Moreover, it is important to note that the basic concept of threat in international relations has significantly changed in terms of agency and scope. In the 1990s and later, the so called Copenhagen (constructivist) school of security studies has successfully identified new agents and sectors of security [Buzan 1991:431-451]. And if traditionally, the primary agent of security studies was the state. Today, it has been joined by other agents and "[...] we must recognize that the very terms stability and security are increasingly perceived and defined in non-military terms. [Neuhold 1992: 197]" Constructivists argued against the view that the core of security studies, like was mentioned before in traditional realist paradigm, is war and force and that other issues are relevant only if they relate to war and force. Thus, the Copenhagen school, in turn, has identified and highlighted new sectors of security: environmental, economic, societal, military, and political.

Fig. 1 portrays the concept of security that has been extended in accordance with constructivist thinking in international relations vertically and broadened horizontally.

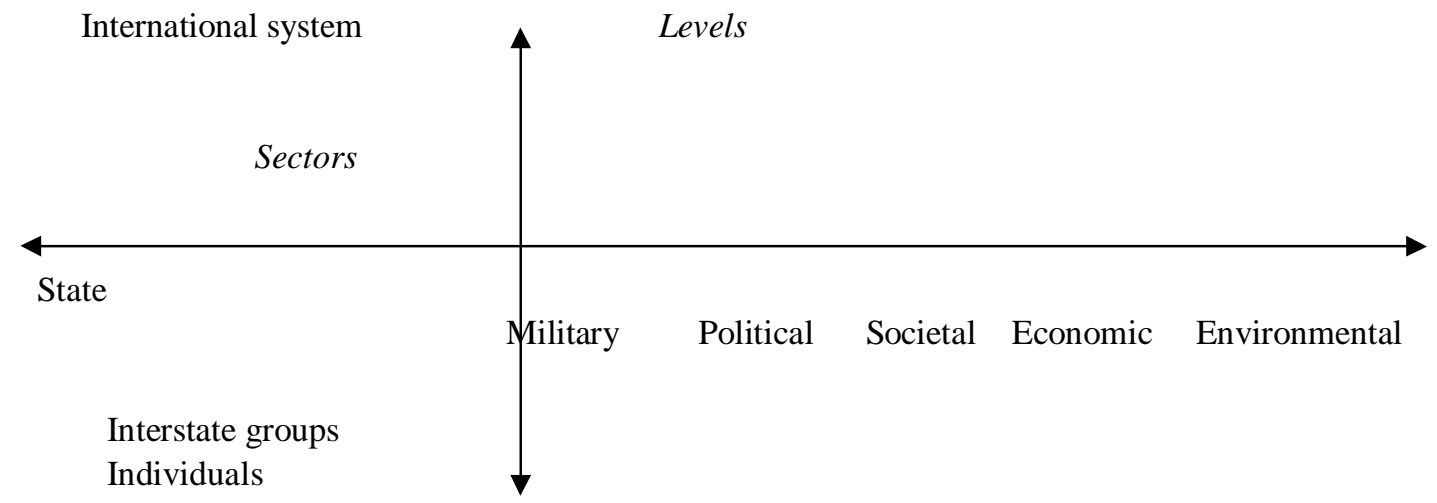

Fig. 1. Combination of vertical and horizontal levels according to constructivist thinking in international relations 
Hence, one can speak of the notion of comprehensive security which consists of both, military and non-military security. Herewith, like constructivists Barry Buzan, Ole Wæver and Jaap de Wilde argue in their book Security: a new framework for analysis "Threats and vulnerabilities can arise in many different areas, military and non-military, but to count as security issues they have to meet strictly defined criteria that distinguish them from the normal run of the merely political. They have to be staged as existential threats to a referent object by a securitizing actor who thereby generates endorsement of emergency measures beyond rules that would otherwise bind [Buzan 1998:5]".

Whilst defining the terms existential threat and emergency measures, the aforementioned researchers claim that this "[...] will vary greatly across different sectors and levels of analysis; in the military sector, the referent object is usually the state, although it may also be other kinds of political entities. In the political sector, existential threats are traditionally defined in terms of the constituting principle-sovereignty, but sometimes also ideology-of the state. In the economic sector, national economies have a greater claim to the right of survival, but rarely will a threat to that survival actually arise apart from wider security contexts, such as war. In the societal sector, given the conservative nature of "identity" it is always possible to paint challenges and changes as threats to identify, because "we will no longer be us," no longer the way we were or the way we ought to be to be true to our "identity."In the environmental sector, the range of possible referent objects is very large, ranging from relatively concrete things, such as the survival of individual species or types of habitat, to much fuzzier, larger-scale issues, such as maintenance of the planetary climate and biosphere [...]. [Buzan 1998: 21-23]”.

Noteworthy, the interplay among all of these sectors is immensely complicated. In addition, the aforementioned changes in the concept of security generated by the process of globalisation as well as by the end of the Cold War, as it was mentioned above, have altered the views on neutrality and one can argue with Agius that "[...]neutrality has disappeared de facto from the official security discourse. [Agius 2006: 36]" Furthermore, one can be of the opinion that under the conditions of globalization, there seemed to be no one to be called neutral in between. And if one takes it, he should perceive that neutrality was not pushed to the periphery, but became considered part of an era, that is an era of bipolarity during the Cold War that was, by then, over. Consequently, neutrality began to represent the past. Many neutrals felt forced to limit the policy from that of neutrality to military non-alignment which is in fact only the core of neutrality [Яворская 2006].
These changes provoked discussions with contradicting conclusions; the relevance of neutrality in contemporary international relations has been very much disputed.

One can claim neutrality is an anachronism and countries that give short shrift to global engagement in the name of neutrality will be marginalized by the new global economy and made irrelevant in international relations. And the new formulation provided by the neutral states with the opportunity of determining its policy freely in wartime is convincing evidence, too. In this context reasonably worthy mentioning Sweden's Prime-Minister Carl Bildt who once stated that Sweden as a neutral state could not be "passive" if the Baltic countries were attacked [Tepe 2007].

Nevertheless, none of the neutrals has explicitly abandoned its traditional security policy so far. Most of the changes have only been manifested in a new, or increased, cooperation with various international institutions.

Ireland stays in the European Union, and cooperates in the areas of the evolving European foreign and security policy. In 1995, Austria, Finland and Sweden entered the EU, and cooperate as well. In 2002, Switzerland entered the UN. India as the classic example of a non-aligned state has "[...] refused to be content with equality and was keen to assert its superiority [Walker 1996: 65-66]" not only in the region, but worldwide.

Nonetheless, it is still too early to claim that neutrality in the globalized world is a feature of the state's weakness and helplessness. Inversely, in my opinion, neutrality in the global tide of changes might be considered an active foreign and security policy strategy, whose successful implementation needs certain more specific efforts. Especially, it concerns professionalism and to a great degree improvement of such two instruments of foreign policy as the army and diplomacy. Hence, an ability to sustain the balance between the belligerents using diplomatic means, and protect state territory and its integrity, independence and inviolability of a neutral status against violations is the first and only characteristic of the mastery of a modern neutral state. Perhaps, we will have to abandon the old concept of neutrality, but what is remain to be constant is that through credibility of impartiality, neutrals today bring something unique to the system of the international relations, especially, when its actors seem intransigent and issues seem intractable; and neutrality, in turn, becomes an indispensible element for stability and ensuring of national security of a state, even in the age of globalization. So, as it was noted in this chapter, historically, each neutral state had its own prerequisites for choosing the status of neutrality. The principles of neutrality have been clearly stipulated in international 
law and should be respected in the way they are laid out. However, since the time of the Hague Conventions many issues and circumstances within the international system have dramatically changed. The twentieth century brought the biggest changes in the history of international relations, evidencing all three known types of international order: multipolarity, bipolarity and unipolarity. The two World Wars, the Cold War, and the post-Cold War period, especially, created deep changes in the political order, international relations, foreign policy, and states' security strategies.

In addition to it, changes in the security field, globalization, also directly or indirectly affected neutral states. A neutral state today cannot be expected to act in a way that was relevant before: time modifies neutrality. A pivotal feature of a neutral status becomes not only the location within the dynamic system of interaction between the great powers and blocs, but also own state's capability to urgently respond to the challenges of modernity.

\section{СПИСОК ЛІТЕРАТУРИ}

Удовик, С. (2002). Глобализация. Семиотические подходы. Москва: Рефл-бук, Ваклер.

Яворская, Г.(2006). "Внеблоковый статус: политический продукт второй свежести.” Зеркало Недели, 15(594), 22-28 апреля 2006. Отримано 3: http://www.zn.ua/ 1000/1600/53235/> [2010 11 15].

Agius, C. (2006). The social construction of Swedish neutrality. Challenges to Swedish identity and sovereignty. Manchester, New York: Manchester University Press.

Buzan, B. (1991). "New Patterns of Global security in the Twenty-First Century." International Affairs, 67(3).

Buzan, B., Ole, W., (1998). de Wilde, J. (ed.), (1988). Security: a new framework for analysis. Boulder/London: Lynne Rienner Publishers. Deutsch.

Burton, J. W. (1966). Non-Alignment. London: Andre

Castro, F. (1979). "Fidel Castro speech to the UN in his position as chairman of the non-aligned countries movement." Austin: Latin American Network Information Center. Retrieved from: http://lanic.utexas.edu/la/cb/cuba/castro/1979/19791012> [2010 11 10].

Hveem, H., Willets, P. (1975). "The practice of nonalignment. On the Present and Future of an International Movement". Africa International, 1: Horizon of African Diplomacy.

Kegley, C. W., Wittkopf E. R. (1997). World Politics: Trend and Transformation. New York: St. Martin's Press.

Lawson, S. (2002). "After the Fall: International Theory and the State". Book: Stephanie Lawson (ed.), The New
Agenda for International Relations: From Polarization to Globalization in World Politic? Cambridge: Polity Press.

McWilliams, W. C., Harry Piotrowski, H. (2005). The world since 1945: a history of international relations. $6^{\text {th }}$ ed. USA: Lynne Rienner Publishers.

Tepe, F. F. (2007) "Swedish Neutrality And Its Abandonment". Istanbul: Istanbul Commerce University. Retrieved from: http://www.iticu.edu.tr/Kutuphane/dergi/ s11/M00167.pdf> [2010 11 15].

Walker, W. (1996). "India's Nuclear Labyrinth." Nonproliferation Review, 4(1).

\section{REFERENCES}

Agius, C.(2006). The social construction of Swedish neutrality. Challenges to Swedish identity and sovereignty. Manchester, New York: Manchester University Press.

Buzan, B. (1991). "New Patterns of Global security in the Twenty-First Century". International Affairs, 67(3).

Buzan, B., Ole, W., (1998). de Wilde, J. (ed.), (1988). Security: a new framework for analysis. Boulder/London: Lynne Rienner Publishers.

Burton, J. W. (1966). Non-Alignment. London: Andre Deutsch.

Castro, F. (1979). "Fidel Castro speech to the UN in his position as chairman of the non-aligned countries movement". Austin: Latin American Network Information Center. Retrieved from: http://lanic.utexas.edu/la/cb/cuba/castro/1979/19791012> [2010 11 10].

Hveem, H., Willets, P. (1975). "The practice of nonalignment. On the Present and Future of an International Movement". Africa International, 1: Horizon of African Diplomacy.

Kegley, C. W., Wittkopf E. R. (1997). World Politics: Trend and Transformation. New York: St. Martin's Press.

Lawson, S. (2002). "After the Fall: International Theory and the State". Book: Stephanie Lawson (ed.), The New Agenda for International Relations: From Polarization to Globalization in World Politic? Cambridge: Polity Press.

McWilliams, W. C., Harry Piotrowski, H. (2005). The world since 1945: a history of international relations. $6^{\text {th }}$ ed. USA: Lynne Rienner Publishers.

Tepe, F. F. (2007) "Swedish Neutrality And Its Abandonment". Istanbul: Istanbul Commerce University. Retrieved from: http://www.iticu.edu.tr/Kutuphane/dergi/s11/ M00167.pdf> [2010 11 15].

Udovyk, S. (2002). Globalization. Semiotic approach. Moscow: Refl-book, Vakler.

Walker, W. (1996). "India's Nuclear Labyrinth". Nonproliferation Review, 4(1).

Iavorska, H. (2006). “ Non-alignment status: politician product of second fresh" Weekly mirror, 15(594), 22-28 апреля 2006. Retrieved from: http://www.zn.ua/1000/1600/53235/> [2010 11 15]. 